Editorial changes have been underlined

or otherwise noted on this proof.

\title{
THE SHADOW OF EXPLOITATION IN Weber's Class ANALYSIS
}

\author{
ERIK OLIN WRIGHT \\ University of Wisconsin-Madison
}

This analysis has two basic objectives: First, to understand as precisely as possible the inner structure of Weber's concept of class, its similarities and differences from Marx's concept, and its relationship to the problem of exploitation; second, to use this interrogation of Weber's work to defend the importance of the concept of exploitation for sociological theory. To understand the foundations of Weber's class analysis one must look beyond his most synoptic treatments of class in Economy and Society and see how his concept of class is intimately linked to his investigations of the broad problem of rationalization in modern society. Class, in these terms, is the way economic power is distributed when economic action is organized to the greatest degree in an instrumentally-rational manner. The problem of exploitation-the extraction of labor effort from workers-is treated, in this framework, primarily as a problem of technical efficiency and economic rationality in creating work incentives and effective discipline. This conceptualization leads to a relatively impoverished understanding of the nature of antagonistic interests generated by class relations.

F THEORETICAL frameworks are identified as loudly by their silences as by their proclamations, then one of the defining characteristics of class analysis in the Weberian tradition is the virtual absence of a systematic concept of exploitation. Nothing better captures the central contrast between the Marxist and Weberian traditions of class analysis than the difference between a class concept centered on the problem of life chances in Weber and a concept rooted in the problem of exploitation in Marx. This is not to say that Weber completely ignores some of the substantive issues connected to the problem of exploitation. For example, Weber, like Marx, sees an intimate connection between the nature of property relations in capitalism and the problem employers face in eliciting high levels of effort from workers. But he does not theorize this issue in terms of a general concept of exploitation, nor does he see the problem of extracting la-

Direct all correspondence to Erik Olin Wright, Department of Sociology, University of Wisconsin-Madison, 1180 Observatory Drive, Madison, WI 53706 (wright@ssc.wisc.edu). bor effort as a pivotal feature of class relations and a central determinant of class conflict. Instead, Weber treats the problem of eliciting work performance within capitalism as an instance of technical inefficiencies reflecting a tension between formal rationality and substantive rationality within capitalist economic relations.

In this paper, I pursue two basic objectives: first, to understand as precisely as possible the inner structure of Weber's concept of class, its similarities and differences from Marx's concept, and its relationship to the problem of exploitation; second, to use this interrogation of Weber's work to defend the importance of the concept of exploitation for sociological theory. The first two sections that follow set the context of the discussion by briefly situating the problem of class in Weber's larger theoretical project and then examining a number of striking similarities between Weber's and Marx's concepts of class. Although Marxist and Weberian traditions of sociology are often pitted against one another, within the narrower arena of class analysis there is considerable overlap, particularly in their concept of class in capi- 
talist society. The third section then characterizes the pivotal difference in their class concepts through the contrast between "life chances" and "exploitation." A fourth section looks more closely at exploitation, paying particular attention to the way Weber deals with the problem of "extracting" labor effort under conditions that Marxists would describe as "exploitation." Finally, the last section examines the ramifications for the broader contours of a sociological analysis of class of Weber's marginalization of the issue of exploitation.

\section{THE LOCATION OF CLASS ANALYSIS IN WEBER'S WORK}

Unlike Marx, for whom class was a foundational concept in his broad theoretical agenda, the problem of class plays a relatively peripheral role in Weber's work. ${ }^{1}$ It appears in his work in three principle ways. First, there are the rare explicit theoretical discussions of class, most notably in the chapter fragments assembled posthumously in Economy and Society. ${ }^{2}$ Second, early in

${ }^{1}$ Because of the peripheral status of class in the Weberian oeuvre, it is surprising that so much of the literature on class sees Weber as a central source. Sørenson (2000) suggests that Weber's prominence in class analysis comes from the accident that his work on class was translated into English:

The importance of the Weberian class concept in the literature on class analysis is a bit curious. In Economy and Society Weber deals with class in two places but both are very short fragments. While Marx can be said to never have given a single explicit development of the class concept, he certainly has class as the central concern of analysis in all of his writings. For Weber, there is neither a discussion nor an extensive analysis. Class simply seems not to have been an important concept for Weber. . . Since only Marx and Weber [among the German writers on class] have been translated into English, Weber has become the main justification for developing class concepts that are alternative to Marx's, despite the fragmentary nature of Weber's writings about this and the lack of importance of class concepts in his writings. (P. 1527, note 3 )

\footnotetext{
${ }^{2}$ The chapter in Economy and Society in which Weber proposes to define the concept of class (pt. 1, chap. 4, "Status Groups and Classes") is unfinished. In a footnote to the first place in the text in which Weber refers to this chapter, the
}

Weber's career there are a number of detailed empirical and historical studies in which the analysis of class figures prominently-most notably his studies of East Elbian agricultural workers (Weber [1894] 1989), his research on the causes of the decline of the Roman Empire (Weber [1896] 1988), and his more general work on the agrarian sociology of ancient civilizations, first published in the late 1890s and then revised in 1909 (Weber [1909] 1988). ${ }^{3}$ Much of this work, especially the work on slavery in ancient civilizations, has a decidedly Marxian inflection and has had almost no impact on the analysis of class within what has come to be known as Weberian sociology. ${ }^{4}$ Third, a great deal of Weber's work concerns the analysis of capitalism as a social order-its origins, its internal logic, its dynamics of development, its ramifications, its contrasts with other social orders-and while the problem of class is rarely explicitly foregrounded in these analyses, nevertheless much of what he says bears

editors of the English edition of the text comment: "This chapter is . . a mere fragment which Weber intended to develop on a scale comparable with the others. Hence most of the material to which this note refers was probably never written down" (Weber [1922] 1978: 210, note 45).

3 A detailed exegesis of Weber's work on agrarian class relations can be found in Käsler (1988).

4 The analysis in Weber's 1896 study of the causes of decline of ancient civilizations has a particularly Marxian flavor to it. His central argument is that the contradictions of slavery as a way of organizing production was the fundamental cause of the ultimate collapse of the Roman Empire. Although Weber's later concerns with issues of rationality and calculability in economic relations are already present in this early work, its main preoccupation is with the difficulty of extracting adequate surplus in a slave-based economy once slavery is no longer based on capturing slaves in slave hunts, and the resulting transformations of the political conditions of reproduction of the Roman Empire. If one did not know that this piece was written by Weber, most people would assume it was a fairly sophisticated Marxist analysis of how the development of this particular kind of class system tended to erode the conditions of its own reproduction. For further discussion of this Marxian influence in Weber's early work, see Schroeter (1985:6-7). For a contrary view, which denies that this work has a significant Marxian character, see Roth (1971). 
on the problem of understanding classes in capitalist societies. For example, Weber's The Protestant Ethic and the Spirit of Capitalism ([1904] 1958) is not simply about the creation of the cultural-psychological conditions for modern capitalism to become a dynamic force in the world; it is also about the ways in which this "spirit" is embodied in the distinctive orientations of people located in different class positions within capitalism. Weber writes, "The treatment of labour as a calling became as characteristic of the modern worker as the corresponding attitude towards acquisition of the business man" (p. 179). ${ }^{5}$

Most discussions of Weber's work on class are based on the first of these clusters of writings, especially on his brief explicit conceptual analyses of class in Economy and Society ([1922] 1978). ${ }^{6}$ What has become the Weber-inspired tradition of class analysis is largely based on these fragmentary expositions (e.g., Giddens 1973; Parkin 1971; Scott 1996). Locating the concept of class within Weber's conceptual menu in these texts generates the familiar contrast of "class" and "status," the two most important terms in a threefold schema of stratification that also includes "party."7 Two primary analytical di-

5 The details of Weber's argument about the psychological ramifications of the ethic of ascetic Protestantism for the spirit of capitalism are familiar. Two more specific citations will suffice. For the Protestant bourgeoisie, Weber (1904

This part still not clear to me. Am I missing something here? Insert

"and" between "profitmaking" and "justified"? [1958]) writes, "as a performance of duty in a calling ... [wealth] is not only morally permissible, but actually enjoined ... the providential interpretation of profit-making justified the activities of the businessman" (p. 163). For the worker, on the other hand, "Labour must . . . be performed as if it were an absolute end in itself, a calling. . . . The ability of mental concentration, as well as the absolutely essential feeling of obligation to one's job, are here most often combined with a strict economy which calculates the possibility of high earnings, and a cool self-control and frugality which enormously increase performance" (pp. 61, 63).

${ }^{6}$ When Weber's work is excerpted in anthologies on stratification, the selections concerning class are almost exclusively from these few explicit definitional statements of Economy and Society (e.g., see Bendix and Lipset 1966; Giddens and Held 1982; Grusky 2001).

7 The chapter in Economy and Society that is the principle source for commentaries on mensions demarcate these categories: first, the "sphere" or "order" within which social interaction occurs (economic, communal, or political $),{ }^{8}$ and second, the degree to which the category intrinsically invokes subjective identity and collective forms of action. The combinations of these criteria differentiate class, status, and party as illustrated in Table 1. Within this analytical schema, class is defined within the sphere of economic interaction and involves no necessary subjective identity or collective action. An individual can be in a specific kind of class situation without this generating a specific form of identity or participation in collective action: "In our terminology, 'classes' are not communities; they merely represent possible, and frequent, bases for social action" (Weber [1922] 1978: 927). Status groups are defined within the sphere of communal interaction (or what Weber calls the "social order") and always imply some level of identity in the sense of some recognized "positive or negative social estimation of honor" (Weber [1922] 1978: 932). A status group cannot exist without its members being in some way conscious of being members of the group: "In contrast to classes, Stände (status groups) are normally groups" (Weber [1922] 1978:932). Status groups need not, however, imply any kind of collective action. Party, finally, always implies collective action: "As over against the actions of classes and status groups, for which this is not necessarily the case, party-oriented social action always in-

Weber's approach to class is titled "The Distribution of Power within the Political Community: Class, Status, Party" (Weber [1922] 1978:92640). Nearly all of this chapter, however, is devoted to class and status, with only one page at the end discussing "party."

8 The terms Weber ([1922] 1978) uses to differentiate these spheres of social interaction are "economic order," "social order" or "the sphere of the distribution of honor," and "the sphere of power" (p. 938). This is somewhat confusing terminology because class, status, and party all concern questions of power (and thus power should not simply be identified with "party"), and all also involve social action (and thus the social should not simply be identified with status). It is for this reason that the terminological distinction between economic, communal, and political seems more useful in the present context. 
Table 1. Theoretical Location of the Concept of Class in Weber's Explicit Formulations in Economy and Society

\begin{tabular}{lc|ccc}
\hline \hline \multirow{2}{*}{$\begin{array}{c}\text { Sphere of } \\
\text { Social } \\
\text { Interaction }\end{array}$} & $\begin{array}{c}\text { Category That Locates } \\
\text { Individuals within the } \\
\text { Distribution of Power }\end{array}$ & $\begin{array}{c}\text { Attributes Intrinsic to Categories } \\
\text { of the Distribution of Power }\end{array}$ \\
\cline { 3 - 5 } Economic & Class & Yes & Subjective & $\begin{array}{c}\text { Collective } \\
\text { Action }\end{array}$ \\
\hline Communal & Status group & Yes & No & Yo \\
\hline Political & Party & Yes & Yes & Yes \\
\hline
\end{tabular}

a Weber's terms for these spheres are "economic order," "social order" or "sphere of the distribution of honor," and "sphere of power" (Weber [1922] 1978:938).

volves association. For it is always directed toward a goal which is striven for in a planned manner" (Weber [1922] 1978:938). In these terms, members of a class become a status group when they become conscious of sharing a common identity, and they become a party when they organize on the basis of that identity. ${ }^{9}$

The conceptual contrast between class and status for Weber is not primarily a question of the motives of actors: It is not that status groups are derived from purely symbolic motives and class categories are derived from material interests. Although people care about status categories in part because of their importance for symbolic ideal interests, class positions also entail such symbolic interests, and both status and class are implicated in the pursuit of material interests. As Weber ([1922] 1978) writes, "material monopolies provide the most effective motives for the exclusiveness of a status group" (p. 935). Rather than motives, the central contrast between class and status is the nature of the mechanisms through which class and status shape inequalities of the material and symbolic conditions people's lives. Class affects material well-being directly through the kinds of economic assets people bring to market exchanges. Status af-

\footnotetext{
${ }^{9}$ Jones (1975) argues that because of the inherent qualities of collective action, members of class as defined by Weber could not even in principle act as a collective agent on the basis of their class interests because collective action requires forms of identification and rationality beyond mere instrumental interests.
}

fects material well-being indirectly, through the ways that categories of social honor underwrite various coercive mechanisms that, in Weber's ([1922] 1978) words, "go hand in hand with the monopolization of ideal and material goods or opportunities" (p. 935).

When the wider body of Weber's work is taken into consideration, especially his diverse writings on capitalism, the problem of class becomes embedded in a different conceptual space. Here the pivotal question is the relationship between the concept of class and the broad theoretical and historical problem of rationalization of social relations. Table 2 indicates how class is located with respect to this problem. ${ }^{10}$ As in Table 1 , this conceptual space is also defined by two dimensions: first, the sources of social power within social interactions, and second, the degree of rationalization of social relations. Running throughout Weber's work is a threefold distinction in the sources of power that individuals use to accomplish their goals: social honor, material resources, and authority. Each of these, in turn, can be organized within social interactions in highly rationalized forms or in relatively nonrationalized forms. Class, in these terms, designates highly rationalized social relations that govern the way people get access to and use

${ }^{10}$ Unlike Table 1, which is derived from the relatively explicit, if underdeveloped, theoretical statements by Weber about the properties of the concept of class and its contrast to other concepts, the typology in Table 2 is inferred from various arguments dispersed throughout Weber's work. 
Not sure I Table 2. The Theoretical Location of “Class" in Weber's Analysis of Rationalization

like this

big empty $>$

space.

What do

you think?

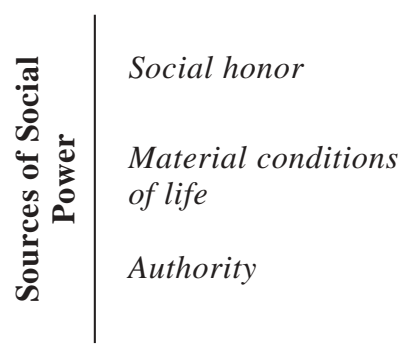

\begin{tabular}{|l|l|}
\multicolumn{2}{c}{ Degree of Rationalization of Social Relations } \\
\hline \multicolumn{1}{c}{ Rationalized Social Relations } & Nonrationalized Social Relations \\
\hline Meritocractic prestige & Ascriptive status groups \\
\hline $\begin{array}{l}\text { Class: } \\
\text { capital, labor }\end{array}$ & $\begin{array}{l}\text { Ascriptively based } \\
\text { consumption groups }\end{array}$ \\
\hline $\begin{array}{l}\text { Rational-legal domination: } \\
\text { bureaucracy }\end{array}$ & $\begin{array}{l}\text { Patrimonial } \\
\text { administration }\end{array}$ \\
\hline
\end{tabular}

material resources. ${ }^{11}$ It is thus contrasted, on one hand, with nonrationalized ways of governing access to resources, especially ascriptively based consumption groups, and on the other hand, with rationalized forms of social relations involving other sources of social power.

Rationalization, of course, is perhaps the most complex multidimensional concept in Weber's arsenal. Following Levine's (1985: 210) decomposition of Weber's conceptual array of rationalizations, the problem of class with Weber is primarily situated within one particular form of rationalization: the objective instrumental rationalization of social order. ${ }^{12}$ In all societies, the ways people

${ }^{11}$ A number of commentators on differences between Weber and Marx have emphasized the centrality of the problem of rationalization in Weber's analysis of capitalism (e.g., see Jones 1975; Löwith [1932] 1982; Sayer 1991). Jones and Sayer, in particular, link the problem of rationalization explicitly to Weber's analysis of classes.

${ }^{12}$ Levine (1985) differentiates eight different forms of rationality in Weber's work. To the standard distinction between instrumental rationality (the rationality of adopting the best means for given ends) and value rationality or substantive rationality (the rationality of choosing actions that consistent with value commitments), he adds conceptual rationality (the formation of increasingly precise and abstract concepts) and formal rationality (the creation of methodical, rationally defendable rules). Within each of these four types of rationality, he then distinguishes between objective rationality (rationality inscribed in institutionalized norms) and subjective rationality, (rationality in mental processes). After elaborating these forms of rationalization that occur in Weber's writing, Levine adds one dis- gain access to and use material resources is governed by rules that are objectively embodied in the institutional settings within which they live. When the rules allocate resources to people on the basis of ascriptive characteristics, and when the use of those material resources is given by tradition rather than the result of a calculative weighing of alternatives, then economic interactions take place under nonrationalized conditions. When those rules enable people to make precise calculations about alternative uses of those resources, and when they discipline people to use those resources in more rather than less efficient ways on the basis of those calculations, then those rules can be described as "rationalized." This occurs, in Weber's analysis, when market relations have the most pervasive influence on economic interactions (i.e., in fully developed capitalism). His definition of classes in terms of the economic opportunities people face in the market, then, is simultaneously a definition of classes in terms of rationalized economic interactions. Class, in these terms, assumes its central sociological meaning to Weber as a description of the way people are related to the material conditions of life under conditions in which their economic interactions are regulated in a maximally rationalized manner.

Two examples, one a discussion of rural class relations from early in Weber's career

tinction not found so explicitly in Weber's work: Within each of the four forms of objective rationalization, Levine differentiates what he terms symbolic rationalization and organizational rationalization. The final result, then, is a typology of 12 forms of rationalization (Levine 1985:210). 
and the second a discussion of industrial class relations in Economy and Society, illustrate this close link in Weber's thinking between rationalization and class relations. Both Weber and Marx recognized the importance of the destruction of traditional peasant rights in the countryside as a central part of the development of capitalism in agriculture. In Weber's early writings on East Elbian rural labor, he describes the impact of this process on class relations in terms of rationalization. Prior to the infusion of market relations in the countryside, Weber (1894] 1989) writes, the rural laborer "found himself confronted not with an 'employer' but with a small-scale territorial lord. The low level of commercial ambition among estate owners was reinforced by the apathetic resignation of the labourer. .." (p. 161). The advance of capitalism destroyed these traditional labor relations. The resulting impact on class relations, Weber describes as a process of rationalization:

[I]n place of the landed aristocracy there necessarily enters-with or without a change of person - a class of agricultural entrepreneurs who are in principle no different to commercial entrepreneurs in their social characteristics.

This transformation in the general type of rural employer has significant consequences for the position of the labourer. ... [In the patriarchal estate economy,] labour relations were not arranged according to commercial principles and with the objective of profitability, but rather developed historically as a means of affording the landlords a suitable existence. Under these conditions as little deviation as possible was made from the natural and communal economic foundations of this order. Thus a rural working class with common economic interests could not and did not exist in the principal regions of the east.

Modern development seeks initially to introduce the principle of economic rationality into the wage forms within this natural economic order. Accordingly, the communal remnants (plots of land, threshing shares, grazing rates) are initially abolished. ...

With this transformation a necessary condition of the patriarchal relation collapses: the connection to one particular estate. The differentiation between various categories of labour are reduced and the employer becomes as "fungible" for the rural worker as he already is for the industrial labourer. In other words, this process of development brings the rural labourers steadily closer to the form of a unified class of a proletarian type in its material conditions of life, a state already attained by the industrial proletariat." (Pp. 63, 172)

The emergence of a rural proletariat thus represents the transformation of forms of access to material conditions of life governed by tradition to one governed by calculation and pure economic interests.

The same basic argument appears in Weber's analysis of the industrial working class. For Weber, as for Marx, a central defining characteristic of the "working class" is its complete separation (or "expropriation") from the means of production. For Marx, this is crucial because it enables capitalists to exploit workers; for Weber this expropriation is crucial because it allows for the full realization of economic rationality within production. In his extended discussion of this separation in Economy and Society, Weber ([1922] 1978) stresses the relevance of expropriation for economic rationality:

The expropriation of workers in general, including clerical personnel and technically trained persons, from possession of the means of production has its economic reasons above all in the following factors: ... The fact that, other things being equal, it is generally possible to achieve a higher level of economic rationality if the management has extensive control over the selection and the modes of use of workers, as compared with the situation created by the appropriation of jobs or the existence of rights to participate in management. These latter conditions produce technically irrational obstacles as well as economic irrationalities. In particular, considerations appropriate to smallscale budgetary administration and the interests of workers in the maintenance of jobs ("livings") are often in conflict with the rationality of the organization. (Pp. 137-38, italics in original)

Similar discussions can be found in Weber's ([1909] 1958:53-56) analysis of the relationship between rationalization and free wage labor in The Protestant Ethic ${ }^{13}$ and in his

13 "However all these peculiarities of Western capitalism have derived their significance in the last analysis only from their association with the capitalistic organization of labour. . . Exact cal- 
discussions of the inefficiencies in slavery (Weber [1909] 1988:53-56). In all of these cases, the problem of the rationalization of the economic order is the central theoretical problem in which analyses of class and the transformations of class relations are embedded. While class per se may be a relatively secondary theme in Weber's sociology, it is, nevertheless, intimately linked to one of his most pervasive theoretical preoccupationsrationalization.

In the discussion that follows, I draw on both of these theoretical contexts of Weber's thinking about class - the contrast between class and status as two forms of stratification, and the salience of rationalization in defining the theoretical relevance of class. Weber's distilled contrast between class and status is particularly useful in clarifying the substantive criteria embodied in his definition of class relations in terms of marketbased life chances; the broader analysis of rationalization will help to illuminate the ways in which Weber deals with the problem of exploitation in capitalist society.

\section{WEBER AND MARX ON CLASS: CONVERGENCES}

There is a long history of discussions of the relationship between Marx's and Weber's social theories, beginning with occasional comments by Weber ([1918] 1971) himself, most famously in his discussion of the Communist Manifesto in a speech to Austrian officers towards the end of World War I. Although Weber was appreciative of Marx's theoretical formulations, he was highly critical of its excessive materialism and dismissive of the utopianism of Marx's theory of history, with its optimistic deterministic prediction of the transcendence of capitalism and the disappearance of classes and the state. Much of the subsequent discussion of Marx and Weber has also revolved around the sharp differences in the broad contours of their respective general theoretical frameworks for understanding the trajectory of historical change - in particular the contrast between Marx's historical materialism as a

culation - the basis of everything else-is only possible on a basis of free labour" (Weber [1904] 1958:22). quasi-teleological theory of history, and Weber's multidimensional theory of historical development and contingency. ${ }^{14}$ When the focus of comparison has centered on stratification issues, the central theme in most discussions has also been the contrast between Marx's preoccupation with a single aspect of stratification - class - and Weber's complex multidimensional view, in which the relationship between class and other bases of stratification, especially status, is of central concern. ${ }^{15}$ Relatively less attention has been given to the fact that, in spite of the different salience of class within the overall theoretical agendas of Marx and Weber, there are deep similarities between the concepts of class in these two traditions of social theory. ${ }^{16}$ To give precision to the specific problem of the location of exploitation within class analysis, I first review these strong similarities.

${ }^{14}$ Although much of the commentary on Weber and Marx's overall frameworks focus on the differences in their approaches, some accounts emphasize significant convergences. For example, Löwith ([1932] 1982) discusses the relationship between Weber's concept of rationalization and Marx's concept of alienation in their theories of modern capitalism, and Sayer (1991) analyzes their respective understandings of modernity. For anthologies of comparative analyses of Marx and Weber, see Antonio and Glassman (1985) and Wiley (1987).

${ }^{15}$ For a recent, analytically rigorous discussion of Marx's and Weber's approaches to class that stresses the contrast between the multidimensional character of Weber's approach and Marx's preoccupation with a single dimension, see Scott (1996).

16 Some writers have noted similarities between Weber's and Marx's class concepts. Bendix (1974:152) sees Weber's analysis of class as departing from a "baseline that Marx had established"; Holton and Turner (1989:181) observe that "both Marx and Weber are concerned with market relations in the constitution of classes"; Giddens (1973) sees Weber, like Marx, characterizing capitalism as a "class society"-a society within which class is the primary axis of stratification. Still, in each of these cases, the observation of similarity is given much less weight than are the differences between Marx's and Weber's class concepts. Sayer (1991) is one of the few writers who regards the differences between Marx's and Weber's approaches to both class and status to be of secondary importance. 


\section{RELATIONAL RATHER THAN GRADATIONAL CLASS CONCEPTS}

Both Marx and Weber adopt relational concepts of class. Neither defines classes simply as nominal levels on some gradational hierarchy. For both, classes are derived from an account of systematic interactions of social actors situated in relation to each other. Classes for both Weber and Marx are thus not primarily identified by quantitative names like upper, upper-middle, middle, lower-middle, and lower, but by qualitative names like capitalists and workers, debtors and creditors. (For more on relational and gradational concepts of class, see Ossowski 1963; Wright 1979, 1997:5-8.)

\section{THE CENTRALITY OF PROPERTY RELATIONS}

Both Marx and Weber see property ownership as the fundamental source of class division in capitalism. For Marx, classes are defined by the "relation to the means of production," where "relation" here means ownership and control over resources used in production. Similarly, Weber ([1922] 1978) writes, "Property' and 'lack of property" are, therefore, the basic categories of all class situations" (p. 927). What is more, Weber, like Marx, sees propertylessness as an essentially coercive condition: "[Those who are propertyless] have nothing to offer but their labor or the resulting products and ... are compelled to get rid of these products in order to subsist at all" (Weber [1922] 1978: 927). ${ }^{17}$ He even acknowledges, like Marx, that for the working class the apparently freely chosen, voluntary interactions of the market are simply a formal reality, masking an essentially coercive structure of social relations (which he refers to as "heteronomously determined action"):

\footnotetext{
${ }^{17}$ In an earlier statement in Economy and Society, while discussing economic motivations, Weber ([1922] 1978) writes: "[T]he motivation of economic activity under the conditions of a market economy ... for those without substantial property [include] the fact that they run the risk of going entirely without provisions ..." (p. 110). Also see Weber's ([1927] 1961:209) discussion of the "compulsion of the whip of hunger" in his General Economic History.
}

[Action that is motivated by self-interest can still be] substantively heteronomously determined ... [in] a market economy, though in a formally voluntary way. This is true whenever the unequal distribution of wealth, and particularly of capital goods, forces the nonowning group to comply with the authority of others in order to obtain any return at all for the utilities they can offer on the market. . . In a purely capitalist organization of production this is the fate of the entire working class. (Weber [1922] 1978:110)

Although this statement may lack the rhetorical force of Marx's account of the essential unfreedom of the worker, the point is fundamentally the same: Being separated from the means of production forces workers to subordinate themselves to capitalists.

\section{Classes-as-Places VERSUS Classes- AS-COLLECTIVE-ACTORS}

Central to the conception of class in both Weber and in Marx is a distinction between classes as objectively defined places and as collectively organized social actors. The language they use to describe this contrast, of course, differs. Weber ([1922] 1978:302, 927) uses the expression "class situation" to designate the objectively defined places within social relations; Marx uses the expression "class-in-itself," and contemporary Marxists have used the expressions "class location" or "class position" or "class structure," depending on the context. Weber ([1922] 1978:305) uses the expression "class conscious organization" to designate class as a collectively organized social actor; Marx uses the expression "class-for-itself," and contemporary Marxists use a variety of terms, such as "class formation" or "class organization." But regardless of terminology, the basic idea is similar: Structurally defined classes may have a tendency to generate collectively organized forms of struggle, but the two must be conceptually distinguished.

\section{Classes AND MATERIAL INTERESTS}

Both Weber and Marx see objectively definable material interests as a central mechanism through which class locations influence social action. By objectively definable ma- 
terial interests I mean that an outside observer can, in principle, specify which courses of action that are available to an individual by virtue of their location in a social structure would improve that person's material conditions of life. Both Marx and Weber claim that (1) a person's class location, defined by their relation to property, systematically affects material interests in this sense; and (2) material interests so defined do influence actual behavior. These claims are relatively uncontroversial for Marx, even though much debate has been waged over whether "class interests" in Marxism are "objective." Weber, on the other hand, is often characterized as a theorist who emphasizes the subjective meanings of actors and who rejects the idea of a determinate relation between objectively specified conditions and subjective states of actors. Nevertheless, in his discussion of class, material interests rooted in individuals' objectively defined class situations are seen as a determinant-albeit a probabilistic determinant_of their behavior. Weber [1922] 1978) writes:

According to our terminology, the factor that creates "class" is unambiguously economic interest, and indeed, only those interests involved in the existence of the market. Nevertheless the concept of class-interest is an ambiguous one: even as an empirical concept it is ambiguous as soon as one understands by it something other than the factual direction of interests following with a certain probability from the class situation for a certain average of those people subjected to the class situation. (Pp. 928-29, italics added)

Thus, Weber affirms that "for a certain average of those people subjected to the class situation" there is a "certain probability" that the "factual direction of interests" will coincide with class interests. Weber thus allows for deviations between individual behavior and the material interests associated with class situations, but he also argues that there is at least a tendency, on average, for behavior to be in line with those interests.

Of course, the expression "a certain probability" is rather vague and leaves open the possibility that this probability could be extremely low and thus the relationship between objectively defined class interests and the "factual direction of interests" could be very weak. Two earlier passages in Economy and Society suggest that Weber in fact believed that purely self-interested economic advantage had a high probability of giving "factual direction" to motivations of most people much of the time. The first passage comes in a discussion of economic motivations within the formation of organizations. Weber ([1922] 1978) writes:

Economic considerations have one very general kind of sociological importance for the formation of organizations if, as is almost always true, the directing authority and the administrative staff are remunerated. If this is the case, an overwhelmingly strong set of economic interests become bound up with the continuation of the organization, even though its primary ideological basis may in the meantime have ceased to exist. (Pp. 201-202, italics added)

Even more starkly, in a discussion of economic activity in a potential socialist society, Weber believes that motivations will be similar to those in a market society, and he thus expresses considerable skepticism about the possibility that ideological commitments will matter very much in socialism. In the long run, Weber ([1922] 1978) argues, most people will be motivated by self-interested material advantage, just as in a market economy:

What is decisive is that in socialism, too, the individual will under these conditions [in which individuals have some capacity to make economically relevant decisions] ask first whether to him, personally, the rations allotted and the work assigned, as compared with other possibilities, appear to conform with his own interests.... [It] would be the interests of the individual, possibly organized in terms of the similar interests of many individuals as opposed to those of others, which would underlie all action. The structure of interests and the relevant situation would be different [from a market economy], and there would be other means of pursuing interests, but this fundamental factor would remain just as relevant as before. It is of course true that economic action which is oriented on purely ideological grounds to the interests of others does exist. But it is even more certain that the mass of men do not act in this way and that it is an induction from experience that they cannot do so and never will. (P. 203, italics added) 
This is a powerful affirmation of the factual predominance of subjective orientations derived from objectively definable material interests: Although it is theoretically possible that ideological motivations could be important, the mass of people do not act on purely ideological grounds and, furthermore, "they cannot do so and never will." For both Weber and Marx, therefore, the material interests structured by class locations have a strong tendency to shape the actual behavior of people within those locations.

\section{THE CONDITIONS FOR COLLECTIVE Class ACTION}

If there is one aspect of class analysis where one might expect a sharp difference between Marx and Weber, it is in their understanding of the problem of class struggle. Although both may believe that class situations shape individual class behaviors via material interests, Marx believed that capitalism inherently generates collectively organized class struggles, eventually culminating in revolutionary challenges to capitalism, whereas Weber rejects this prediction. Yet, even here, there is more similarity in their views than one might initially expect.

In assessing arguments of this sort, it is important to distinguish (1) the theoretical analysis of the conditions under which particular predictions hold, in this case that class struggles are likely to emerge and intensify, from (2) the empirical expectations about the likelihood of those conditions actually occurring. In these terms, Weber shares much with Marx in terms of the first consideration, but disagrees sharply over the second. ${ }^{18}$

In Economy and Society in a section labeled "social action flowing from class interest," Weber ([1922] 1978) lays out some of the conditions that he feels are conducive to collectively organized class struggles:

\footnotetext{
${ }^{18}$ Bendix (1974) recognizes that Weber shares with Marx many elements of the theory of the conditions under which class mobilization is likely to succeed: "[C]lass organizations occur only when an immediate economic opponent is involved, organization is technically easy (as in the factory), and clear goals are articulated by an intelligentsia. ... Weber accepted Marx's reasons for the success of such organizations" (p. 152).
}

The degree to which "social action" and possibly associations emerge from the mass behavior of members of a class is linked to general cultural conditions, especially to those of an intellectual sort. It is also linked to the extent of the contrasts that have already evolved, and is especially linked to the transparency of the connections between the causes and the consequences of the class situation. For however different life chances may be, this fact in itself according to all experience, by no means gives birth to "class action' (social action by members of a class). For that, the real conditions and the results of the class situation must be distinctly recognizable. For only then the contrast of life chances can be felt not as an absolutely given fact to be accepted, but as a resultant from either (1) the given distribution of property, or (2) the structure of the concrete economic order. It is only then that people may react against the class structure not only through acts of intermittent and irrational protest, but in the form of rational association.... The most important historical example of the second category (2) is the class situation of the modern proletariat. (Pp. 929-30)

This complex paragraph involves several very Marxian-like theses: First, the emergence of class associations depends on intellectual conditions; it is not simply the result of unmediated spontaneous consciousness of people in disadvantaged class situations. This is congruent with Marx's view of the role of ideological mystification in preventing class organization and the importance of class-conscious intellectual leadership in raising working-class consciousness, a theme stressed in different ways by later Marxists such as Gramsci and Lenin.

Second, where class structures are experienced as natural and inevitable, as "absolutely given facts," class mobilization is impeded. Weber points here to the central issue that Marx, especially in his discussion of commodity fetishism and capital fetishism, also identifies as the most important intellectual obstacle to class consciousness: the belief in the naturalness and permanency of the existing conditions and thus the impossibility of any fundamental change. Much of Marx's work, in fact, can be viewed as an attempt at a scientific challenge to such apparent "naturalness" in the belief that such demystification would contribute to forging revolutionary consciousness. 
Third, the transparency of class relations facilitates class mobilization. Marx also believed that class mobilization would be more difficult where there were lots of intermediary classes-petty bourgeois, peasants, professionals-than where class structures were highly polarized and the causal connection between the class structure and the conditions of people's lives were transparent. This is an important part of Marx's prediction that capitalism's destruction of all precapitalist economic relations and the immiseration of the proletariat would lead to intensified class conflict.

Last, because of the relative transparency of their class situation, the modern proletariat comes to understand that "the contrast of life chances ... [is the result of] the structure of the concrete economic order" (p. 929). Modern capitalism therefore creates the required kind of transparency for class associations of workers to be likely.

Weber and Marx thus share many elements in the theoretical specification of the conditions for class associations to emerge, and Weber shares with Marx at least the limited expectation that these conditions will be minimally satisfied in the case of the modern proletariat in capitalist economies so that class associations and class struggles are likely to occur. Where they differ-and this is a difference that matters-is in the empirical prediction that the inner dynamics of capitalism are such that these conditions will be progressively strengthened over time, leading to a systematic tendency for long term intensification of class struggles within capitalism. If Marx's empirical predictions about these conditions had been correct, then Weber would have shared with Marx the prediction that class conflicts would have a tendency to continually intensify in the course of capitalist development. Where they differ, therefore, is in their predictions about the long-term trajectory of capitalism more than in their views about the conditions under which capitalism would engender a classconscious organized working class. ${ }^{19}$

${ }^{19}$ Another instance in which Weber shares Marx's theoretical analysis of conditions for effective, collective class mobilization, is in their respective analyses of the peasantry. Marx ([1852] 1970) is famous for arguing, in The Eigh-

\section{CLASS AND STATUS}

Finally, Marx and Weber even have some similar things to say theoretically in an area where sociologists generally think they are most divergent: in their treatment of the relationship between class and status. A central issue in Weberian sociology is the enduring importance of status groups as a source of identity and privilege. As such, status groups are seen as competing with class as bases of solidarity and collective action. Marx shared with Weber the views that (1) status groups impede the operation of capitalist markets, and further, that (2) they constitute an alternative basis of identity to class formation. And Weber shared with Marx the view that (3) capitalist markets tended to erode the strength of status groups and their effects on the system of stratification. ${ }^{20}$ Weber ([1922] 1978) writes:

When the bases of the acquisition and distribution of goods are relatively stable, stratification by status is favored. Every technological repercussion and economic transformation threatens stratification by status and pushes the class situation into the

teenth Brumaire of Louis Bonaparte, that in spite of their common class interests, peasants had little capacity for collective action because they were so dispersed in the countryside and remained as separate entities with no interdependency-like a "sack of potatoes." Weber ([1894] 1989) makes a similar point about East Elbian peasants: "For the [agricultural] labourer then the possibility of brutal personal domination that could be only escaped by flight gave way to commercial exploitation which, arising almost unnoticed, was actually much harder to evade and which as a smallholder he was not in a position to do. Formal equality then placed the labourers in a struggle of interests for which, dispersed far over the land as they were, they lacked the means of resistence" (p. 171).

${ }^{20}$ Mommsen (1985) makes the even stronger claim that, from early in his career, Weber believed that capitalism would not merely erode traditional status orders, but destroy them: "As early as 1893 Weber predicted that within a few generations, capitalism would destroy all tradition-bound social structures and that this process was irreversible" (p. 234). Most sociologists drawing on Weber's work assume that status remains a salient dimension of stratification even though capitalism would significantly reduce its weight as a mechanism of identity and exclusion. 
foreground. Epochs and countries in which the naked class situation is of predominant significance are regularly the periods of technical and economic transformations. (P. 938)

Using different rhetoric, Marx and Engels ([1848] 1968) in the Communist Manifesto made parallel arguments:

Constant revolutionizing of production, uninterrupted disturbances of all social conditions, everlasting uncertainty and agitation distinguish the bourgeois epoch from all earlier ones. All fixed, fast-frozen relations, with their train of ancient and venerable prejudices and opinions, are swept away. (P. 38)

The reference to "all fixed, fast-frozen relations" taps the same kinds of categories that Weber theorized as "stratification by status," and Marx and Engels, like Weber, see these relations threatened by "revolutionizing of production, ... disturbances of all social conditions," or what Weber termed "periods of technical and economic transformations." So, both Marx and Weber see capitalism as undermining status groups and fostering a predominance of what Weber called "naked class situation." They may have differed in their beliefs about the long-term consequences of this development for class mobilization and struggle-Marx believed it would reinforce tendencies towards polarized class struggle, whereas Weber believed that the development of capitalism was producing a much more complex class structure less vulnerable to polarized struggle ${ }^{21}$ _but

${ }^{21}$ In Weber's ([1918] 1971) "Speech for the General Information of Austrian Officers in Vienna," in which he puts forth an extended discussion of Marxism and the prospects of socialism in Germany, Weber explains how changes in class structure tie the interests of large numbers of people to the bourgeoisie:

Parallel to these very complex processes, however, there appears a rapid rise in the number of clerks, i.e., in private bureaucracy-its growth rate is statistically much greater than that of the workers-and their interests certainly do not lie with one accord in the direction of a proletarian dictatorship. Then again, the advent of highly diverse and complicated ways of sharing interests means that at the present time it is quite impossible to maintain that the power and number of those directly or indirectly interested in the bourgeois order are on the wane. (P. 207) both saw capitalism as systematically eroding the salience of traditional status groups.

\section{WEBER AND MARX ON CLASS: CENTRAL DIFFERENCES}

If the above analysis is correct, then both Weber and Marx deploy varieties of property-centered relational concepts of class in which, among other things, (1) objectively definable material interests play a central role in explaining class action, (2) class structure and class struggle are distinguished, (3) collective class action is facilitated by class polarization, and (4) the dynamic processes of capitalism create conditions favorable to class playing a pervasive role in systems of stratification. Where they differ most sharply is in their understanding of the causal mechanisms that are linked to such propertyrelational classes. For Weber, the pivotal issue is how classes determine the life chances of people within highly rationalized forms of economic interactions-markets; for Marx, the central issue is how class determines both life chances and exploitation. ${ }^{22}$

The basic idea of the determination of life chances by class is laid out in Weber's ([1922] 1978) frequently cited passage:

We may speak of a "class" when (1) a number of people have in common a specific causal component of their life chances, in-

${ }^{22}$ This is not the only way to characterize the core difference between Marx's and Weber's conceptualization of class. Other synoptic contrasts include: production versus exchange (Burris 1986; Collins 1986), unidimensional versus multidimensional (Burris 1986; Scott 1996), and dichotomous versus pluralistic class concepts (Giddens 1973). Other authors who discuss the life chances versus exploitation contrast include Crompton and Gubbay (1977:3-20) and Wright (1997). Sayer (1991) also identifies the problem of exploitation as the central difference between Marx and Weber's approach to class, although he is skeptical that this matters very much: "On the question of exploitation there remains an unbridgeable gulf between Marx and Weber, which reflects the very different economic theories-respectively political economy and marginalismupon which their sociologies of capitalism are predicated. How important this is, I would argue, is debatable.... [A]ltogether too much ink has been wasted over their supposed differences" (pp. 104-105). 
sofar as (2) this component is represented exclusively by economic interests in the possession of goods and opportunities for income, and (3) is represented under the conditions of the commodity or labor markets. This is "class situation."

It is the most elemental economic fact that the way in which the disposition over material property is distributed among a plurality of people, meeting competitively in the market for the purpose of exchange, in itself creates specific life chances....

But always this is the generic connotation of the concept of class: that the kind of chance in the market is the decisive moment which presents a common condition for the individual's fate. Class situation is, in this sense, ultimately market situation. (Pp. 92728)

"Opportunity" in this context is a description of the feasible set individuals face, the tradeoffs they encounter in deciding what to do to improve their material conditions. The Weberian claim is that in a market societya society in which people acquire the wherewithal to live by exchanging things with others in an instrumentally rational way- such opportunities are caused by the quality and quantity of what people have to exchange. When markets are fully and pervasively present, opportunities are not mainly caused by economically irrelevant ascriptive attributes or by individuals' control of violence, but by the resources a person can bring to the market for exchange. Owning the means of production gives a person different alternatives from owning credentials, and both of these differ from simply owning unskilled labor power. Furthermore, in a market economy, access to market-derived income affects a broad array of life experiences and opportunities for oneself and one's children. The study of the life-chances of children based on parent's market capacity-the problem of class mobility-is thus an integral part of the Weberian agenda of class analysis. Within a Weberian perspective, therefore, the salient consequence that flows from people's links to different kinds of economic resources deployed in markets is the way these links confer on them different kinds of economic opportunities and disadvantages, thereby shaping their material interests.
This definition is intimately connected to the problem of rationalization. When people meet to make an exchange in a market, they rationally calculate the costs and benefits of alternatives on the basis of the prices they face in the market. These prices provide the kind of information required for people to make rational calculations, and the constraints of market interactions force them to make decisions on the basis of these calculations in a more or less rational manner. Weber is, fundamentally, less interested in the problem of the material deprivations and advantages of different categories of people as such, or in the collective struggles that might spring from those advantages and disadvantages, than he is in the underlying normative order and cognitive practices-instrumental rationality - that are embodied in the social interactions that generate these life chances.

Marx would agree with Weber that the ownership of different resources used in market exchanges affects life chances. And like Weber, he recognizes that exchanges in the market constitute interactions based on calculation and instrumental rationality. ${ }^{23}$ But in Marx's class analysis, the effect of exchange on life chances is only half the story. Of equal significance is how property relations shape the process of exploitation. Both "exploitation" and "life chances" identify inequalities in material well-being that are generated by inequalities in access to resources of various sorts. Thus, both of these concepts point to conflicts of interest over the distribution of the assets. What exploitation adds to this is a claim that conflicts of interest between classes are generated not simply by conflicts over the distribution and value of resources people bring to exchanges in the market, but also by the nature of the interactions and interdepen-

${ }^{23}$ In Capital ([1867] 1967, vol. 1), Marx describes exchange relations between labor and capital as taking place in a sphere in which " $[\mathrm{t}] \mathrm{he}$ only force that brings them together and puts them in relation with each other, is the selfishness, the gain and the private interests of each" (p. 176). Although he does not use the language of rational instrumental action, the description here is entirely in line with Weber's view of market exchange. 
dencies generated by the use of those resources in productive activity.

Exploitation, for Marx, identified the process by which labor effort performed by one group of economic actors is extracted and appropriated by another group. That appropriated labor is referred to as "surplus labor," meaning laboring activity above and beyond what is required to reproduce the laborers themselves. In capitalism, for Marx, this appropriation occurs because employers are able to force workers to work longer hours and perform more labor than is embodied in the products that they consume with their wages. Expressed in the classical language of the labor theory of value, the labor value of what they produce is greater than the labor value of what they consume. The difference-surplus value-is appropriated by the capitalist. This appropriation is exploitation. ${ }^{24}$

The concept of exploitation, defined in this way, is used by Marx in two general explanatory contexts. First, Marx sees exploitation as the source of profits in capitalism: Capitalists appropriate surplus value from workers that, when capitalists sell the commodities embodying that surplus value, is turned into money profits. Profits, in turn, are essential for investment and capital accumulation. In this way, exploitation figures centrally in Marx's account of the dynamics of capitalism. Second, Marx sees exploitation as central to explaining the particular character of conflict between workers and capi-

24 Although Marx elaborated the concept of exploitation in terms of the labor theory of value, as a sociological concept exploitation does not depend on this technical apparatus. As I have argued (Wright 1997:4-17), class exploitation can be understood as a social relation in which (1) the material well-being of exploiters occurs at the expense of the well-being of the exploited, (2) this inverse relation depends upon the exclusion of the exploited from access to material resources, and (3) this exclusion from access to resources enables exploiters to appropriate of the labor effort of the exploited. Taken together, these three criteria imply a relationship in which the advantaged groups depend on the efforts of the disadvantaged groups for the reproduction of their advantages. For a trenchant philosophical discussion of why the concept of exploitation does not logically depend on the labor theory of value, see Cohen (1988). talists. Exploitation constitutes a social relation that simultaneously pits the interests of one class against another, binds the two classes together in ongoing interactions, and confers upon the disadvantaged group a real form of power with which to challenge the interests of exploiters. This is an important point. Exploitation depends on the appropriation of labor effort in ongoing social interactions. Because human beings are conscious agents, they always retain significant levels of control over their expenditure of effort. The extraction of effort within exploitative relations is thus always to a greater or lesser extent problematic and precarious, requiring active institutional devices for its reproduction. Such devices can become costly to exploiters in the form of the costs of supervision, surveillance, sanctions, and so on. The ability to impose such costs constitutes a form of power among the exploited.

The exchange relations that shape life chances also involve conflicts of interest. Yet, in an idealized competitive market in which direct coercion is absent from the exchange process itself, these conflicts are muted by the apparent voluntariness of the act of exchange. As Weber ([1922] 1978) remarks, "Exchange' is a compromise of interests on the part of the parties in the course of which goods or other advantages are passed as reciprocal compensation. ... Every case of rationally oriented exchange is the resolution of a previously open or latent conflict of interests by means of a compromise" (p. 72). Marx ([1867] 1967), similarly, sees the market exchanges between workers and capitalists as involving reciprocity and a degree of commonality of interests:

[Exchange between labor and capital implies] [e]quality, because each enters into relation with the other, as with a simple owner of commodities, and they exchange equivalent for equivalent. ... The only force that brings them together and puts them in relation with each other, is the selfishness, the gain and the private interests of each. Each looks to himself only, and no one troubles himself about the rest, and just because they do so, do they all, in accordance with the pre-established harmony of things, or under the auspices of an all-shrewd providence, work together to their mutual advantage, for the common weal and in the interest of all. (P. 176) 

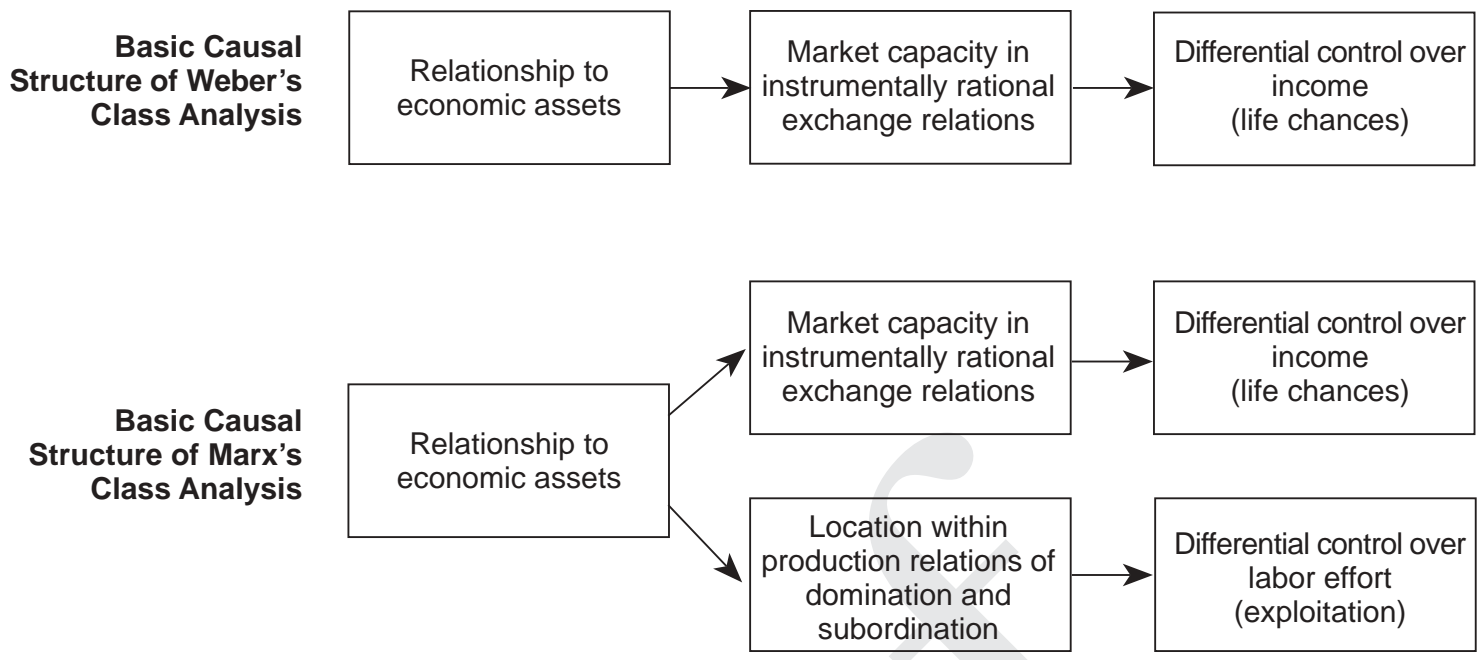

Figure 1. Core Elements in Weber's and Marx's Analysis of Class

Within production, on the other hand, the containment of the conflict of interests between the performers of labor effort and the appropriators of that effort requires the ongoing exercise of domination through complex forms of surveillance, discipline, and control of the labor process. The conflict over exploitation is not settled in the reciprocal compromise of a contractual moment; it is continually present in the ongoing interactions through which labor is performed.

The central difference between Marx's and Weber's concept of class, then, is that the Weberian account revolves exclusively around market transactions, whereas the Marxist account also emphasizes the importance of conflict over the performance and appropriation of labor effort that takes place after market exchanges are contracted. This contrast is illustrated in Figure 1 (modified and simplified from Wright [1997:34]). Weber's class analysis revolves around a single causal nexus that works through market exchange; Marxist class analysis includes the Weberian causal processes, but adds to them a causal structure within production itself. The Marxist concept of class directs our attention both theoretically and empirically toward the systematic interaction of exchange and production.

One of the striking implications of this contrast between the Weberian and Marxist concepts of class is that Weber-at least in his most mature work when he is formalizing his concepts-rejects the idea that slaves are a class, whereas for Marxists slavery constitutes one form of precapitalist class relations. ${ }^{25}$ Weber ([1922] 1978) writes:

Those men whose fate is not determined by the chance of using goods or services for themselves on the market, e.g.., slaves, are not, however, a class in the technical sense of the term. They are, rather, a status group. (P. 928) ${ }^{26}$

For Weber ([1922] 1978), slaves are a specific instance of a general theoretical category-status groups-that also includes ethnic groups, occupational groups, and other categories "that are stratified according to the principles of their consumption of goods as represented by special styles of life" (p. 937). These groups differ by the mean-

${ }^{25}$ For an alternative view of the relationship between class and status in Marx's and Weber's treatment of slavery and feudalism, see Sayer (1991), who argues that Marx used the word "class" in two quite different ways. In one sense, class is a generic term covering all systems of exploitation linked to production; in the other sense, it is specific to capitalism. This second usage of the word, Sayer argues, is the more fundamental to Marx's theory and thus, like Weber, Marx believed that only in capitalism were there fully developed classes.

${ }^{26}$ In Weber's early work on agrarian economies in ancient civilizations, which is marked by a much more Marxian kind of analysis than is his later work in Economy and Society, slaves were treated as a class, and their relationship to slaveowners was treated as involving exploitation. 
ings and criteria that accord differential social honor to different "styles of life," and "slavery" is just one way of organizing such status rankings. In contrast, Marxists would see slavery as, primarily, a special instance of a different general theoretical categoryclass - that includes capitalists and workers in capitalism, lords and serfs in feudalism, slaves and slave-owners in slavery. Although these categories differ in lifestyles and the cultural criteria used to impart symbolic rankings, the crucial issue is their differences in mechanisms of exploitation-the ways in which labor effort is appropriated from one category by another. Marx, of course, like Weber, recognized that in precapitalist societies social division was organized around status orders involving personal dependence and extra-economic coercion. But for Marx the most salient feature of such status orders was how they underwrote distinctive forms of exploitation. It is this which justifies treating these as varieties of the abstract category "class relations" within a class concept centering on exploitation.

\section{THE SHADOW OF EXPLOITATION IN WEBER}

Although Weber's definition of the concept of class says nothing explicitly about exploitation, it is nevertheless the case that in various places in Economy and Society and elsewhere Weber touches on the substantive problems that, within Marxist coordinates, would be characterized as involving the exploitation of labor. How Weber deals with these problems is revealing of the inner logic of his general approach to class analysis. ${ }^{27}$

\footnotetext{
27 The issue here is not the use of the word "exploitation." Even in English this term can mean simply taking advantage of some kind of opportunity, as in "exploiting natural resources," and thus the real meaning of the term must be derived from the context of its use. In any case, a variety of different German words can be translated into the English term "exploitation." The word does appear in a few places in the English translation of Economy and Society and even more frequently in Weber's earlier work on slavery. In Economy and Society, the words in the original German text that are translated as "exploitation" are never the German term used in Marxist technical discussions of exploitation, Ausbeutung, or
}

Weber engages the problem of the performance and appropriation of labor effort within the system of production primarily as an issue of work discipline, the "incentives to work," and economic efficiency. This identification of the problem of extraction of labor effort and technical efficiency is one of the themes in Weber's ([1904] 1958) discussion in The Protestant Ethic of the problem of using piece-rates as a strategy for getting workers to work harder. Here is the relevant passage:

One of the technical means which the modern employer uses in order to secure the greatest possible amount of work from his men is the device of piece-rates. In agriculture, for instance, the gathering of the harvest is a case where the greatest possible intensity of labour is called for, since, the weather being uncertain, the difference between high profit and heavy loss may depend on the speed with which the harvesting can be done. Hence a system of piece-rates is almost universal in this case. And since the interest of the employer in a speeding up of harvesting increases with the increase of the results and the intensity of work, their attempt has again and again been made, by increasing the piece-rates of the workmen, thereby giving them an opportunity to earn what for them is a very high wage, to interest them in increasing their own efficiency. But a peculiar difficulty has been met with surprising frequency: raising piece-rates has often had the result that not more but less has been accomplished in the same time, because the worker reacted to the increase not by increasing but by decreasing the amount of work. ... The opportunity of working more was less attractive than that of working less.... This is an example of what is here meant by traditionalism. A man does not "by nature" wish to earn more and more

even the relatively morally charged term Ausnutzung (which suggests taking unfair advantage). Rather, Weber used the much more neutral terms Benutzung or Verwertung, which basically mean "to use." In his earlier work on slavery, on the other hand, Weber sometimes uses Ausnutzung and occasionally the more technical Marxist term Ausbeutung, again reflecting the greater Marxian character of that work. In one place, he uses the expression exploitationsrate, thus directly invoking the Marxist meaning of exploitation. In his later work, this Marxian usage is completely absent. I thank Phil Gorski for proving me with guidance on these linguistic issues. 
money, but simply to live as he is accustomed to live and to earn as much as is necessary for that purpose. Whenever modern capitalism has begun its work of increasing the productivity of human labor by increasing its intensity, it has encountered the immensely stubborn resistance of this leading trait of pre-capitalistic labor. (Pp. 59-60)

Weber ([1904] 1958) concludes that this technical problem can be effectively solved only when the laborer adopts a set of attitudes toward work-the Protestant work ethic - that generates a moral imperative for him or her to expend a maximum of effort:

Labour must, on the contrary, be performed as if it were an absolute end in itself, a calling. But such an attitude is by no means a product of nature. It cannot be evoked by low wages or high ones alone, but can only be a product of a long and arduous process of education." (P. 61) 28

Weber ([1922] 1978) discusses at greater length in Economy and Society the motivation of workers to expend effort in a discussion of the "conditions affecting the optimization of calculable performance by labor" (p. 150). "Optimization of calculable performance" is a specific problem within the broader discussion of the conditions that foster or impede technical rationality in economic organization. Weber ([1922] 1978) cites three primary conditions for this optimization to occur: "(a) the optimum of aptitude for the function; (b) the optimum of skill acquired through practice; (c) the optimum of inclination for the work" (p. 150).

${ }^{28}$ In The Protestant Ethic, Weber ([1904] 1958) also discusses the reasons why "Low wages are by no means identical with cheap labor," as low wages may lead to a decline in effort and diligence: "Low wages fail even from a purely business point of view wherever it is a question of producing goods which require any sort of skilled labour, or the use of expensive machinery which is easily damaged, or in general wherever any great amount of sharp attention or of initiative is required. Here low wages do not pay, and their effect is the opposite of what was intended" (p. 61). Here Weber is laying out the essential arguments of what is now tellingly referred to as "efficiency wage theory." Again, the extraction of labor effort is treated as a problem of instrumental rationality and efficiency rather than as a problem antagonistic interests.
The third of these concerns the performance of labor effort. Weber ([1922] 1978) writes:

In the specific sense of incentive to execute one's own plans or those of persons supervising one's work [the inclination to work] must be determined either by a strong selfinterest in the outcome or by direct or indirect compulsion. The latter is particularly important in relation to work which executes the dispositions of others. This compulsion may consist in the immediate threat of physical force or of other undesirable consequences, or in the probability that unsatisfactory performance will have an adverse effect on earnings.

The second type, which is essential to a market economy, appeals immensely more strongly to the worker's self-interest. (P. 150)

Weber then discusses a variety of conditions that need to be met in order for this "indirect compulsion," to be effective. He ([1922] 1978) cites three factors: (1) That employers have a free hand in hiring and firing workers: "It also necessitates freedom of selection according to performance, both qualitatively and quantitatively, though naturally from the point of view of its bearing on profit" (p. 150). (2) Workers lack both ownership and control over the means of production: "It presupposes the expropriation of the workers from the means of production by owners is protected by force" (p. 150). (3) Workers bear the responsibility for their own reproduction: "As compared with direct compulsion to work, this systems involves the transferral [of] ... the responsibility for reproduction (in the family) . . . to the workers themselves" (p. 151).

Where the above three conditions are met, workers will expend the optimum amount of effort from the point of view of profits of the capitalist. Where the conditions are not met, labor effort will tend to be restricted, resulting in a decline in technical rationality. In particular, Weber ([1922] 1978) discusses situations in which the first condition is violated-conditions in which workers themselves retain some significant degree of control over the deployment of their labor:

[O]pportunities for disposal of labor services may be appropriated by an organization of workers, either without any appropriation by the individual worker or with important limitations on such appropriation. 
This may involve absolute or relative closure against outsiders and also prohibition of the dismissal of workers from employment by management without consent of the workers, or at least some kind of limitations on powers of dismissal. . . .

Every form of appropriation of jobs in profit-making enterprises by workers ... [results in] a limitation on the formal rationalization of economic activity. (P. 128)

At the core of this limitation on formal rationalization is the problem of labor effort. If workers appropriate their jobs but owners still appropriate the products of labor, technical rationality is limited "through a tendency to restrict the work effort, either by tradition, or by convention, or by contract; also through the reduction or complete disappearance ... of the worker's own interest in optimal effort," (Weber [1922] 1978: 129). Weber goes on to argue that the problem of getting a technically rational level of work effort from workers who control their jobs is similar to the problem of getting work effort from slaves:

The very opposite forms of appropriationthat of jobs by workers and that of workers by owners-nevertheless have in practice very similar results. [When workers are appropriated by owners] it is natural that exploitation of labor services should, to a large extent, be stereotyped; hence that worker effort should be restricted and that the workers have little self-interest in the output. . . Hence, almost universally the work effort of appropriated workers has shown a tendency to restriction....When jobs have been formally appropriated by workers, the same result has come about even more rapidly. (Pp. 129-30)

If one wants the technically most efficient performance of labor effort by workers within production, therefore, workers must not only be expropriated from the means of production, but must also lose any real control over their jobs and the labor process.

One situation in which Weber ([1922] 1978) sees that the appropriation of jobs by workers might not lead to restriction of work effort is where the workers are also owners of the means of production: "The appropriation of the means of production and personal control . . . over the process of workers constitute one of the strongest incentives to un- limited willingness to work" (p. 152). But this situation creates other irrationalities, especially because "the interests of workers in the maintenance of jobs ('livings') is often in conflict with the rationality of the organization" (p. 138). Thus, although it might be the case in a worker-owned cooperative that workers would work very hard, they would engage in technically irrational behavior in their allocation of labor and their unwillingness to hire and fire labor as the market required.

Weber's stance toward the problem of work effort in these passages is broadly in line with that of contemporary neoclassical micro-economics. Most neoclassical economists see any restriction by workers of managerial control of labor and the labor process as generating efficiency losses, both because of technically suboptimal allocations of resources and because of restrictions of labor effort by workers. Like Weber, these economists believe that control of the workplace by workers leads to worker opportunism-workers serving their own interests at the expense of efficiency. The only real solution to such opportunism is preventing workers from appropriating their jobs and making the alternative to conscientious performance of work especially unpleasant. Thus, they would endorse Weber's statement that "[f]ree labor and the complete appropriation of the means of production [by the owner] create the most favorable conditions for discipline" (Weber [1922] 1978:138).

For Weber, the problem of the performance and appropriation of work effort is, thus, above all a question of the degree and forms of rationality in economic organization. This does not mean that Weber ([1922] 1978) was unaware that these forms of rationality may impose harms on workers: "The fact that the maximum of formal rationality in capital accounting is possible only where the workers are subjected to domination by entrepreneurs is a further specific element of substantive irrationality in the modern economic order" (p. 138). Indeed, as Mommsen (1985), Löwith ([1932] 1982), Schroeter (1985), and others have noted, running throughout Weber's work is the view that rationalization has perverse effects that systematically threaten human dignity and welfare, particularly because of the 
ways in which it intensifies bureaucratic domination. ${ }^{29}$ Weber thus hardly held a benign view of capitalism and the work organization it entailed. Nevertheless, he did not treat this problem of extracting work effort as central to the class relations of capitalism and the conflicts of interests that those relations engendered.

\section{RAMIFICATIONS}

All in all, the formal characteristics of the concept of class in capitalist societies are rather similar in Weber and Marx. They differ primarily in the broader theoretical context in which these definitions are embedded and in their accounts of the central causal mechanisms that are linked to class relations. For Weber, these mechanisms are primarily centered in the ways in which ownership of property affects life chances via instrumentally rational exchanges in the market; for Marx, they concern the ways in which ownership of property affects life chances and exploitation through the interplay of markets and production. Although Weber also, if only in passing, touches on issues closely related to exploitation, particularly the problem of labor discipline and domination, he does not integrate these concerns into the general concept of class but treats them primarily as issues in the technical efficiency of systems of production.

One might still ask, so what? Does this really matter? Even if Weber underplayed the

\footnotetext{
${ }^{29}$ Mommsen (1985) describes Weber's stance toward capitalism this way:

Although he vigorously defended the capitalist system against its critics from the Left, . . . he did not hesitate to criticize the system's inhuman consequences. . . . His concern for the preservation of human dignity under the societal conditions created by and typical for mature capitalism (particularly the severe discipline of work and exclusion of all principles of personal ethical responsibility from industrial labor) is entirely consistent with Marx's effort to find a way of overcoming the social alienation of the proletariat under industrial capitalism. (P. 235)
}

Where Weber most deeply differed from Marx is in Weber's belief that socialism, in whatever form, would only intensify this oppression, and thus no viable alternative to capitalism would be possible (unless one was willing to accept a dramatic decline in technical rationality). importance of extraction of labor effort, there is nothing in his framework that actively blocks attention to this issue. And indeed, class analysts in the Weberian tradition have paid varying degrees of attention to the problem of work discipline, labor effort, and related matters.

Nevertheless, there are consequences of elaborating the concept of class strictly in terms of market relations and life chances without a systematic connection to the problem of exploitation. Conceptual frameworks matter because, among other things, they direct thinking and research in particular ways. Here I would emphasize two issues: First, the ways in which explicitly linking exploitation to the concept of class changes the way class conflict is understood, and second, the ways exploitation infuses class analysis with a specific kind of normative concern.

The concept of exploitation draws attention to the ways in which class conflicts do not simply reflect conflicting interests over the distribution of a pie. Rather, to characterize class relations as exploitative emphasizes the ways in which exploiting classes are dependent upon the exploited class for their own economic well-being, and because of this dependency, the ways in which exploited classes have capacities for resistance that are organic to the class relation. Because workers always retain some control over the expenditure of effort and diligence, they have a capacity to resist their exploitation; and because capitalists need workers, there are constraints on the strategies available to capitalists to counter this resistance. ${ }^{30}$

${ }^{30}$ As I have argued elsewhere (Wright 1997: 11-12), the ways in which exploitation acts as a constraint on the exploiter is revealed in historical situations in which sharp conflicts over exclusion from economic resources occur in the $a b$ sence of exploitation. There is a morally abhorrent folk-saying from nineteenth-century United States, "the only good Indian is a dead Indian." Such a saying has a kind of grotesque "rationality" in the context of the struggles between European settlers and indigenous people over control of the land: Although there were sharp and violent conflicts with Native Americans over their expulsion from the land, in general the labor effort of Native Americans was not exploited, and thus the white settlers did not depend upon Native Americans for their own prosperity. Na- 
Exploitation thus entails a specific kind of duality: conflicting material interests plus a real capacity for resistance. This duality has implications for the way we think about both the individual and collective power of workers: As individuals, the power of workers depends both on the scarcity of the kind of labor power they have to offer in the labor market (and thus their ability to extract individual "skill rents" through the sale of their labor power) and on their ability to control the expenditure of their individual effort within the labor process; as a collectivity, workers' power depends on their ability to collectively regulate the terms of exchange on the labor market (typically through unions) and their ability to control the organization of work, surveillance, and sanctions within production. The concept of exploitation, therefore, suggests a research agenda in which class conflict and the balance of class power must be understood in terms of the systematic interplay of interests and capacities within both exchange and production.

When the appropriation of labor effort is treated, not in terms of the basic social relations that bind together workers and capitalists, but in terms of the formal rationality of the "conditions affecting the optimization of calculable performance by labor" (Weber [1922] 1978:150), the issue of the performance of labor effort becomes analyzed primarily as a technical problem of overcoming the traditionalism or opportunism of workers as individuals. Capitalists face a wide range of problems in enhancing rational calculability in economic action. One problem revolves around the work perfor-

tive Americans were thus "dispensable" from the settlers' point of view. The parallel aphorisms in the case of slavery or workers in capitalist firms might be something like, "The only good slave is a docile slave," or "The only good worker is an obedient worker" (or in Weber's analysis, "a worker with a Protestant work ethic"), but it would make no sense to say, "The only good slave is a dead slave," or "The only good worker is a dead worker." It is in this sense that exploitation acts as a constraint on the strategies of exploiters: They must seek ways of responding to resistance of the exploited that reproduce, rather than destroy, their interactions with the exploited. mance of employees. The most fundamental solution to this problem is for workers to develop the right kinds of attitudes, as described in The Protestant Ethic and the Spirit of Capitalism. When workers see the performance of labor effort as a callingwhen they have the proper work ethic - then the problem of optimizing the calculable performance of labor is greatly reduced, perhaps even eliminated. In the absence of this ethic, then, even with close supervision, the actual extraction of optimal levels of effort is an enduring problem. Instead of understanding the capacity of workers to control their own effort as a fundamental source of class-based power available to workers in their class struggles with capitalists, Weber sees this control as one of the obstacles to forming a fully rationalized economic order.

Beyond the issue of the conceptual mapping of research agendas, Marx's and Weber's conceptual frameworks direct class analysis toward different sets of normative concerns linked to the material interests of different classes. Both theorists ask questions and pursue agendas rooted in their values, although Weber is undoubtedly more self-conscious than Marx about trying to keep his values from shaping his conclusions. ${ }^{31}$ The issue here is that the specific way the concept of class is built directs attention toward different kinds of normative agendas.

Weber's treatment of work effort as primarily a problem of economic rationality directs class analysis toward a set of normative concerns centered above all on the interests of capitalists: efficiency and rationalization. Although Weber is not blindly uncritical of capitalism and recognizes that, from the point of view of workers, the organization of work may be "substantively irrational," throughout his discussion of work

${ }^{31}$ Weber, of course, is famous for arguing that social science should attempt to be "objective" in the sense of trying to restrict its moral concerns to the posing of questions rather than to the substance of research and the selection of answers. Marx also believed in scientific objectivity, but was skeptical that in social analysis the analyst could in practice keep the substance of ideas from being influenced by the analyst's own relationship to social forces-especially class interests-in the society. 
effort the emphasis is on how arrangements that enhance worker control and autonomy are technically irrational. Whether or not Weber was sympathetic to the conditions of workers, this preoccupation is very much in line with the interests of owners and managers. In contrast, the Marxist tradition of linking the problem of work effort to exploitation directs class analysis toward normative concerns centered on the interests of workers. The issue becomes not simply a question of which arrangements are the most technically efficient from the point of view of profit maximization but of how particular ways of organizing exchange and production impose harms on workers. Marxists recognize that increasing exploitation is "efficient" from the point of view capitalist economic organization, but the conceptual framework constantly brings to the foreground the ways in which this imposes harms on workers and poses the question "under what conditions can such harms be challenged and eliminated?"

Erik Olin Wright is Vilas Professor of Sociology at the University of Wisconsin-Madison. His work has mainly centered on the development of the Marxist tradition in sociology, with particular focus on class analysis. His most recent books are Class Counts (Cambridge University Press, 1997; student ed., 2000), and (jointly with Archon Fung) Deepening Democracy: innovations in empowered participatory governance (Verso, 2003).

\section{REFERENCES}

Antonio, Robert J. and Ronald M. Glassman, eds. 1985. A Marx-Weber Dialogue. Lawrence, KS: University Press of Kansas.

Bendix, Reinhard. 1974. "Inequality and Social Structure: A Comparison of Marx and Weber." American Sociological Review 39:149-61.

Bendix, Reinhard and Seymour Martin Lipset. 1966. Class, Status, and Power: Social Stratification in Comparative Perspective. New York: Free Press.

Burris, Val. 1986. “The Neo-Marxist Synthesis of Marx and Weber on Class." Pp. 43-64 in The Marx-Weber Debate, vol. 2, Key Issues in Sociological Theory, edited by N. Wiley. Newbury Park, CA: Sage.

Cohen, G. A. 1988. "The Labour Theory of Value and the Concept of Exploitation." Pp. 209-38 in History, Labour and Freedom, edited by G. A. Cohen. Oxford, England: Clarendon Pa- perbacks.

Collins, Randall. 1986. Weberian Sociological Theory. Cambridge, MA: Cambridge University Press.

Crompton, Rosemary and John Gubbay. 1977. Economy and Class Structure. London, England: Macmillan.

Giddens, Anthony. 1973. The Class Structure of the Advanced Societies. New York: Harper and Row.

Giddens, Anthony and David Held. 1982. Classes, Power and Conflict: Classical and Contemporary Debates. Berkeley, CA: University of California Press.

Grusky, David, ed. 2001. Social Stratification: Class, Race, and Gender in Sociological Perspective. Boulder, $\mathrm{CO}$ : Wesview.

Holton, Robert J. and Bryan S. Turner. 1989. Max Weber on Economy and Society. London, England: Routledge.

Jones, Bryn. 1975. "Max Weber and the Concept of Class." The Sociological Review 23:729-59.

Käsler, Dirk. 1988. Max Weber: An Introduction to His Life and Work. Translated by P. Hurd. Chicago, IL and Cambridge, England: Polity.

Levine, Donald Nathan. 1985. The Flight from Ambiguity: Essays in Social and Cultural Theory. Chicago, IL: University of Chicago Press.

Löwith, Karl. [1932] 1982. Max Weber and Karl Marx. Translated by H. Fantel. Reprint, London, England: George Allen and Unwin.

Marx, Karl. [1852] 1970. The Eighteenth Brumaire of Louis Bonaparte. Pp. 97-180 in Selected Works in One Volume, by K. Marx and F. Engles. New York: International Publishers.

—. [1867] 1967. Capital. Vol 1. Reprint, New York: International Publishers.

Marx, Karl and Frederick Engels. [1848] 1968. The Communist Manifesto. Pp. 35-63 in Selected Works in One Volume, by K. Marx and F. Engles. London, England: Lawrence and Wishart.

Mommsen, Wolfgang J. 1985. "Capitalism and Socialism: Weber's Dialogue with Marx." Pp. 234-261 in A Weber-Marx Dialogue, edited by R. J. Antonio and R. M. Glassman, and translated by D. Herr. Lawrence, KS: University of Kansas Press.

Ossowski, Stanilaw. 1963. Class Structure in the Social Consciousness. London, England: Routledge and Kegan Paul.

Parkin, Frank. 1971. Class Inequality and Political Order. New York: Praeger Publishers.

Roth, Guenther. 1971. "The Historical Relationship to Marxism." Pp. 227-46 in Scholarship and Partisanship, edited by R. Bendix and G. Roth. Berkeley, CA: University of California Press. 
Sayer, Derek. 1991. Capitalism and Modernity: An Excursus on Marx and Weber. London, England: Routledge

Schroeter, Gerd. 1985. "Dialogue, Debate, or Dissent: The Difficulties of Assessing Max Weber's Relationship to Marx." Pp. 2-19 in A Weber-Marx Dialogue, edited by R. J. Antonio and R. M. Glassman. Lawrence, KS: University of Kansas Press.

Scott, John. 1996. Stratification and Power: Structures of Class, Status and Command. Cambridge, MA: Polity.

Sørenson, Aage. 2000. "Toward a Sounder Basis for Class Analysis." American Journal of Sociology 105:1523-58

Weber, Max. [1894] 1989. "Developmental Tendencies in the Situation of East Elbian Rural Labourers." Pp. 158-87 in Reading Weber, edited by K. Tribe. New York: Routledge. [1896] 1988. "The Social Causes of the Decline in of Ancient Civilization." Pp. 387411 in The Agrarian Sociology of Ancient Civilizations, translated by R. I. Frank. Reprint, London, England: Verso. . [1904] 1958. The Protestant Ethic and the Spirit of Capitalism. Translated by T. Parsons. Reprint, New York: Charles Scribner's Sons.

[1918] 1971. "Speech for the General Information of Austrian Officers in Vienna. " In Max Weber: The Interpretation of Social Reality, edited by J. E. T. Eldridge and translated by D. Hürch. London, England: Michael Joseph.

[1909] 1988. The Agrarian Sociology of Ancient Civilizations. Translated by R. I. Frank. Reprint, London, England: Verso.

. [1922] 1978. Economy and Society. Edited by G. and C. Wittich. Reprint, Berkeley, CA: University of California Press.

. [1927] 1961. General Economic History. Translated by F. H. Knight. Reprint, New York: Collier.

Wiley, Norbert, ed. 1987. The Marx-Weber Debate. Newbury Park, CA: Sage.

Wright, Erik Olin. 1979. Class Structure and Income Determination. New York: Academic Press.

1997. Class Counts. Cambridge, MA: Cambridge University Press. 